\title{
Ананасы в шампанском (о культурной семантике еды)
}

\author{
ОЛЕГ ФЕДОСОВ \\ ELTE BTK Szláv és Balti Filológiai Intézet, H-1088 Budapest, Múzeum krt. 4/D. \\ E-mail: fedoszov@gmail.com
}

(Received: 26 July 2017; accepted: 14 September 2017)

\begin{abstract}
The paper deals with some food names in Russian (апельсин, ананас) within the framework of linguoculturological approach. The aim of this study is to analyze the main tendencies prevailing in the semantic adaptation of these loanwords that entered the Russian language in the 18th century. The first part is devoted to the conditions of appearance of these words in Russian culture and their semantic characteristics. The second part contains the description of semantic shifts that occur during the formation of cultural connotations of orange and pineapple. The author also demonstrates the manner in which semantic shifts can be used to describe a huge amount of cultural knowledge or cultural information. Proceeding from the notion of "cultural memory", I set out to show that the phraseological meaning is a complex structure including semantic information and its conceptual basis. In my study, I would like to demonstrate what processes go on during its actualization in idiomaticity. The analysis is conducted on the basis of data found in the Russian National Corpus.

Keywords: semantics, Russian, cultural information, cultural connotation, phraseological image, idiomaticity, food names
\end{abstract}

\section{о. Введение}

В когнитивной теории метафоры хорошо известны семантические переходы, переосмысления в направлении от абстрактных сущностей к конкретным. Такой пример приводится и в работе А. Н. Баранова о метафоризации понятия справедливость. В ней, в частности, автор указывает:

Предметное осмысление существенно более разнообразно в профилировании различных смыслов, чем метафора персонификации и строительства... Предметность дает возможность осмыслять справедливость и как ресурс: припасти справедливость, кусочек справедливости, справедливость - самый ходовой политический товар. Близко к ресурсной семантике осмысление справедливости как пищи: хочется то ли Конституции с хреном, то ли севрюжины с социильной справедливостью; насытиться справедливостью (БАРАНОВ 2015: 24).

В настоящей работе мы сделаем попытку проследить за движением в обратном направлении: от конкретных наименований пищи к их символьным, абстрактным значениям. Для анализа и иллюстрации знаков пищевого культурного кода мы выбрали несколько специфических лексем - названий еды. Лексемы ананас и апельсин включены в многочисленные контексты русской 
литературы и культуры, а также являются - как это ни парадоксально на первый взгляд - важными атрибутами культурной истории страны. Этим мы хотели бы обратить внимание на факт, что не только «лингвоспецифические» лексемы как, например, щзи или квас, могут нести в себе важную культурологическую нагрузку.

\section{1. Еда как знак}

Названия пищи, еды могут приобрести знаковое значение и вне культурного контекста. Для иллюстрации «внешне-лингвистических» отношений, в которых ключевую роль играют названия пищи, приведем два примера. Первый получил новую актуальность в связи с политическими событиями весны 2017 г. в Венгрии. «Венгерский апельсин» (Magyar Narancs) - название либерально-демократического журнала, основанного в Венгрии осенью 1989 г., т. е. в разгар венгерской «бархатной революции». Известно, что по соглашению с журналом правящая сегодня партия «Фидес» (Fidesz - первоначально аббревиатура из сочетания «Союз молодых демократов») воспользовалась тогда символикой апельсина в своей первой предвыборной кампании 1990 г., и оранжевый цвет стал отличительным фоном партпропаганды «Фидеса». Название журнала, в свою очередь, было выбрано по ассоциации со ставшей крылатой фразой из сначала запрещенного, но затем ставшего культовым в кадаристской Венгрии фильма режиссера Петера Бачо «Свидетель» (Bacsó Péter: A tanú): «Kicsit savanyú, kicsit sárga..., de a mienk» (букв. 'Немного кислый, немного желтый..., но наш'). В данном эпизоде фильма, действие которого проходит в сталинскую эпоху, вместо «выращенного в социалистической Венгрии» апельсина подсовывается лимон... Вышеназванный журнал долгое время финансировался Фондом Д. Сороса, который в свое время (конец 1980-х гг.) оказал стипендиальную поддержку многим из сегодняшних руководителей страны из правящего «Фидеса». Однако весной 2017 года отношения между этими венгерскими политиками и Д. Соросом обострились настолько, что Сорос был объявлен госпропагандой главным врагом Венгрии и венгерской независимости, а парламент принял закон против будапештского «университета Сороса» (CEU), что в свою очередь вызвало серию массовых антиправительственных демонстраций в апреле-мае 2017 г.

Другой пример взят нами из текста современной российской прессы. В газете «Московский комсомолец» (Саратов, региональное издание) от 2 ноября 2016 г. вышла статья А. Краснова о событиях 1956 г. в Венгрии под названием «Рецепт с кровью: как приготовить мятеж (60 лет назад было подано главное блюдо новейшей истории Венгрии)». В тексте статьи читаем:

Венгерская политическая кухня известна меньше: навскидку вспоминаются разве что классическое правление Иштвана Святого, фашистские выходки адмирала Хорти, сподвижника нацистов в пору Второй мировой, ну и, конечно, так называемый «гулящ-социализм» Яноша Кадара, тридцать лет правившего уже 
социалистической Венгрией... Гулящ-социализм «доели» в 1989-м... В случае с Венгрией - весьма демократичную систему управления и хозяйствования; систему, которая стала возможной только благодаря тому, что 60 лет назад был подавлен кровавый венгерский мятеж, превращавший людей в мясо и в «овощңи». ${ }^{1}$

Этот пример показывает, как современный публицист строит весь текст, начиная с заголовка, на метафорике таких моделей как политика - это кухня, мятеж / револючия - это блюдо с кровью, и переинтерпретированных значениях других «пищевых» лексем как, например, овощ( $(u)$ 'инвалид, ментально и /или физически беспомощный человек'.

\section{1. Пример с фраземой гуляш-социализм}

Обратим в приведенном выше тексте внимание и на фразему гулямсоциализм. Трудно представить себе более типичное венгерское блюдо, чем гуляи. В венгерской фразеологии, однако, роль лексемы gulyás 'гуляш' весьма скромная. В словарях мы найдем всего 3 фразеологические единицы (две из них - т. н. монофраземы), где компонентом является гуляи: gulyássá aprít ‘безжалостно избить кого' (букв. 'размельчить в гуляш') (BÁRDOSI 2003: 117); kenyerez, mint a gulyásbojtár 'есть пустой хлеб’ (О. NAGY 1994: 244); gulyáságyú (букв. 'полевая кухня') (ÉKSz. 1: 475).

Выражение gulyáskommunizmus как самостоятельная словарная единица не рассматривается ни в одном словаре, но оно включено в этимологическую справку к фраземе a legvidámabb barakk (букв. 'самый веселый барак в лагере социализма' - ироническое название Венгрии в период от 1970-х гг. до времени смены режима в 1989-1990 гг.). В этой статье В. Бардоши пишет: «Режим Кадара и ее новый экономический механизм часто называли „самым веселым бараком в лагере социализма“, который - в сравнении с более жесткой диктатурой в других соцстранах - по мнению Запада вместо коммунизма строил гуляи-коммунизм и холодильник-социализм» (BÁRDOSI 2015: 62). ${ }^{2}$ Выражение a legvidámabb barakk 'самый веселый барак' в венгерском языке, очевидно, имеет шансы стать самостоятельной фраземой и вне исторического контекста - «в лагере социализма». Совсем недавно в венгерской электронной прессе появился такой заголовок: Mégiscsak a Gazprom legvidámabb barakkja lesz Magyarország? (букв. 'И все же Венгрия станет самым веселым бараком Газпрома?') - в статье, посвященной «газовым геополитическим играм» между Россией и Европой. ${ }^{3}$

\footnotetext{
${ }^{1}$ http://saratov.mk.ru/articles/2016/11/02/60-let-nazad-bylo-podano-glavnoe-blyudo-noveysheyistorii-vengrii.html

${ }^{2}$, „... Kádár-rendszert s annak új gazdasági mechanizmusát gyakran a szocialista tábor »legvidámabb barakkjának« nevezték, mely - összehasonlítva más szocialista országok keményebb diktatúrájával - a nyugatiak szerint pártkommunizmus helyett »gulyáskommunizmust és frizsiderszocializmust « épített”.

${ }^{3} \mathrm{http}: / /$ www.napi.hu/magyar_gazdasag/megiscsak_a_gazprom_legvidamabb_barakkja_lesz_ magyarorszag.644260.html
} 


\section{2. Ананас и апельсин в культурном контексте}

Теперь обратимся к названиям пищи, составившим тему настоящей работы. Но прежде чем оценить роль ключевых лексем в контексте культуры, целесообразно отметить, как фиксирован их образ в наивном языковом сознании, или же в т. н. языковой картине мира.

\section{1. Ананас и апельсин в наивном сознании}

Простой запрос в поисковых системах хорошо иллюстрирует тот факт, что ананас и апельсин - по крайней мере в русском языковом сознании плохо ассоциируются с пищей, с продуктами питания. Безусловно, в кулинарии, гастрономии и специальных областях медицины (например, диететика - наука о рациональном питании) оба «фрукта» присутствуют в этом качестве, но в т. н. «наивном сознании» - нет. Вот типичные контексты:

Не следует употреблять в пищу ананас тем, у кого низкая вязкость крови...

Наукой еще не доказано, способен ли ананас сжигать накопленные жиры. Но достоверно известно, что он улучшает пищеварение, усвоение пищи...

Последний пример показывает, что ананас в наивном сознании лишь «улучшает усвоение пищи», т. е., скорее всего, сам он - не совсем пища. Кроме того, если попытаться в интернете выяснить вопрос: является ли ананас фруктом или овощем - то ответ звучит обычно так: специалисты это до сих пор не решили. Данный факт, конечно же, сам по себе не является чем-то исключительным, что подтверждают и представленные Б. Л. Иомдиным факты из статьи «Что такое орехи?», в которой автор показывает следующее:

Существующие описания толковых словарей несистемны и плохо интерпретируются - в первую очередь потому, что в них смешано бытовое и терминологическое словоупотребление, которые в описываемом материале весьма существенно различаются (так, в ботанике орехом обычно считается каштан, но не считаются кедровый орех, арахис, миндаль, фисташка...). При этом словоупотребление в ряде областей (в частности, в сфере кулинарии, торговли, медицины), как и в быту, отличается от принятого в ботанике (Иомдин 2015: 214).

И в случае ананаса оказалось, что с точки зрения ботаники его плод это ягода, а сам он - многолетнее травянистое плодовое растение. Для бытового сознания, однако, это не имеет никакого значения, поэтому в обыденной речи можно смело называть эти плоды «фруктами»:

Наш язык брал себе те слова, которыми называли за рубежом различные предметы, не встречающиеся в нашей стране: фрукты ананас и апельсин, зверя аллигатора, птицу альбатроса (Л. В. Успенский: Слово о словах, 1971). ${ }^{4}$

\footnotetext{
4 Здесь и далее нами используются примеры из Национального корпуса русского языка (НКРЯ) - http://www.ruscorpora.ru.
} 
Классическое издание советских времен «Книга о вкусной и здоровой пище», одобренная к печати Институтом питания Академии медицинских наук СССР, уделяет ананасу и апельсину всего несколько строк (в примечаниях, мелким шрифтом), просто описывая их свойства. Ни в одном рецепте блюд или салатов, варений, компотов и т. п. эти фрукты не присутствуют. Однако в этой книге мы читаем: «Очень хороши ананасы к вину, особенно к шампанскому» (Покровский 1988: 291).

Поскольку энциклопедические сведения об ананасе и апельсине найти сегодня в мире интернета не представляет никакого труда, опустим эти (сами по себе достаточно интересные) данные, и сосредоточимся на нашей теме. ${ }^{5}$

\section{2. Примеры из публицистики и РАС}

Два примера из современной российской публицистики помогут высказать предварительные предположения о том, какое символьное значение закреплено за лексемами ананас и апельсин в наивном языковом сознании носителей русского языка. При этом первый пример не вербальный, а визуальный. На сайте Полит.ру 29 марта 2017 г. появилась статья Ильи Карпюка под названием «Оптимистический экономический цикл», в которой сообщалось: «Глава Центрального банка Эльвира Набиуллина заявила, что в России начался новый экономический цикл, а национальная банковская система „в целом“" восстановилась после шоков 2014-2015 годов». ${ }^{6}$

Никакого упоминания об ананасах здесь не было, но оптимизм главы ЦБ эта статья подчеркнула фотомонтажом: зрелый ананас посреди зеленого поля.

Другой пример из прессы текстовый: М. Федотов, советник президента РФ по правам человека, в недавнем выступлении о распаде СССР сказал:

15 республик были как дольки в апельсине. Они все были скованы этой союзной «кожурой». Что нужно было сделать? Нужно было убрать «кожуру», те оковы, что мешали республикам развиваться. Ведь невозможно было управлять всем из Москвы. [...] Нужно было этот апельсин просто разделить на дольки. А мы вместо этого бросили его с 12 этажа.

Обоснованным кажется предположение, что ананас - в наивном русском сознании - до сих пор ассоциируется с чем-то дорогим, экзотическим, эксклюзивным и т. п., в то время как «ассоциации по апельсину», его символьные значения этих оттенков не имеют и - в основном - непредсказуемы (ср. выше: бывший СССР в образе апельсина). При этом заметим, что сегодня низкая и доступная цена банки консервированного ананаса в любом гипермаркете вжитому образу ананаса явно не соответствует, в отличие, например,

\footnotetext{
${ }^{5}$ Много данных об истории ананаса в России собрано: см., например, АБАшЕв 2002.

${ }^{6} \mathrm{http}: / /$ polit.ru/article/2017/03/29/nabiullina

${ }^{7}$ https://www.novayagazeta.ru/articles/2017/05/22/72532-my-brosili-apelsin-s-dvenadtsatogo-
} etazha 
от цены крупного зрелого ананаса в середине XIX в. в России, выращенного, скажем, в придворцовой оранжерее в подмосковных Царицыне или Кузьминках. Есть данные, что цена одного такого плода тогда равнялась цене коровы.

Чтобы подтвердить (или опровергнуть) наши подозрения, теперь обратимся к фактам языка, проанализировав некоторые контексты из НКРЯ.

Но перед этим сделаем еще одно замечание. В «Русском ассоциативном словаре» (РАС), т. е. тезаурусе, созданном коллективом под руководством Ю. Н. Караулова, в первом томе слов-стимулов ананас и апельсин, естественно, нет. Но во втором томе ананас включен как реакция к стимулам плод, урожай, покупать, причем с самой низкой частотностью, т. е. всего по одному ответу. Для сравнения укажем, что на стимул покупать дано 32 ответа продукты, на урожай - 31 ответ хлеб и т. д. Примерно такая же ситуация с апельсином, но с важным отличием: он (во множественном числе - aneльcuнь) фигурирует как реакция на стимул очередь. И здесь частотность минимальная - всего один ответ, но это надо сравнить с частотностью 82 для ответа длинная, и 20 для ответа за колбасой. Так же, например, всего по одному ответу на очередь дают: водка, и за водкой в СССР. Соответственно, для апельсинов такой количественный проигрыш по сравнению с колбасой совсем «не позорен», а очередь за апельсинами можно отнести к достаточно типичной ассоциативной связи для русского языкового сознания в советский период (РАC 2: 7-8).

\section{3. Ананас и апельсин в зеркале корпуса}

Что же показывает корпус, и почему его использование необходимо и при лингвокультурологическом исследовании?

Ответ, конечно же, в самом материале. Корпус дает возможность лингвистического анализа языкового материала, аутентичных текстов, при этом сам материал - при внимательном рассмотрении - неизбежно представляет язык в контексте, в данном случае, русской культуры. Текстовый характер материала, естественно, наиболее детально представляет одну область культуры - национальную литературу. Однако в некоторых текстах могут быть отражены феномены и других культурных областей, например, в нашем случае это и кино, и театр, и музыкальные произведения. Так, в ряде текстов мы можем обнаружить, какое влияние произвел на российскую/советскую культуру культовый фильм 1960-х гг. «Заводной (или Механический) апельсин» (A Clockwork Orange) американского режиссера Стэнли Кубрика, или почему Андрей Тарковский во время съемок «Сталкера» заменил лошадь на собаку, а яблоко - на гнилой апельсин и т. д.

Но, по понятным причинам, этими областями культуры в нашем анализе заниматься не будем, а сосредоточимся на отечественной литературе. Объем корпусного материала в случае наших ключевых слов (ананаса и апельсина) поистине огромен, поэтому результаты анализа не могут быть представлены иначе как сжато и схематично, с минимально необходимыми текстовыми 
иллюстрациями. При этом для целей нашего исследования приводить здесь точные количественные, статистические данные не имеет смысла.

Отдельный и, конечно же, очень интересный аспект - это сопоставление корпусного материала с теоретически возможными психолингвистическими экспериментами, например, на присутствие прецедентных текстов (с ананасом и апельсином) в АВС (ассоциативно-вербальной сети - термин Ю. Н. Караулова) носителей языка.

\section{4. «...аромат отобранного у нас всего остального мира»}

Ананас в русском сознании был и (отчасти) остается символом богатства, успеха, роскоши - с одной стороны, и символом «чужого и прекрасного», подчас недоступного, мира за пределами страны - с другой. Апельсин такой символики не имеет, но для советских времен за ним закрепилось представление о «дефиците». Приведем вначале примеры из НКРЯ на символику богатства (заметим, что между временем возникновения текстов разрыв почти в два столетия):

(1) Он держал уже стол à la Ministre: шампанское, aнaнacbl, мороженое и прочее подавалось постоянно; но обедающих было мало, один или двое посторонних, не больше (К. Ф. Аделунг: Письма отцу, 1828).

(2) Была такая песня Анны Герман «Надежда». Я сочинил переделку на тему олигархов... - еще слабым, но чистым голосом Вырин напел: - Скрипнули протяжно тормоза / Возле дорогого магазина. / Грустные еврейские глаза / Дали мне совет из лимузина: / «Надо только выучиться лгать, / Надо стать отпетым пидарасом, / Чтоб порой от жизни получать / Рябчика под сладким ананасом», - Гриша кисло усмехнулся... (Михаил Елизаров: Библиотекарь, 2007).

Более значимыми, однако, нам представляются примеры на символику «чужого/запретного/прекрасного/недоступного»:

(3) На обыкновенном иллюминационном плане фонарями изобразить половинное окружение великаго театра по Римскому обыкновению; на верхних украшениях поставить многие вазы с цветами или деревьями, выбранными изо всех четырех частей света, например, яблони, палмы, алои и ананасы, дабы изобразить, что сей амфитеатр значит весь свет, из четырех частей состоящий (М. В. Ломоносов: Проэкт иллюминации и фейэрверка к торжественному дню возшествия на всероссийский престол Ея Императорскаго Величества ноября 25 дня 1753 года, 1753).

(4) У ананаса был дурманящий аромат отобранного у нас всего остального мира. Благодаря неожиданно доброму капризу государственной торговли, ананасы появились в московских магазинах впервые за все годы после Октябрьской революции именно во время повальных арестов конца тридцатых годов, словно для того, чтобы хоть слегка подсластить жизнь и создать витринную видимость неизолированности от мировой циивилизации. Однако весьма скоро эти, слишком возбуждающие воображение простых советских 
людей, фрукты исчезли по чьему-то, возможно, сугубо идеологическому решению так же внезапно, как появились. Второй настоящий ананас я достал лишь во время хрущевской недолгой «оттепели», когда в Москве впервые выставили Пикассо, пригласили Ива Монтана, джаз Бенни Гудмана и стали продавать итальянские мокасины, гнущиеся в руках, как цирковые гуттаперчевые мальчики без костей. Именно этот ананас я и держал в руках, когда приехал к моей первой жене мириться, но и он мне не помог. И, наконец, мой третий ананас за всю мою советскую жизнь предстал передо мной в Сокольниках, в крохотной кухоньке англичанки. - Откуда это? (Евгений Евтушенко: «Волчий паспорт», 1999).

Мы намеренно привели здесь расширенную цитату из автобиографической прозы Е. Евтушенко, чтобы подчеркнуть факт: в отличие от апельсина у ананаса наряду с символикой богатства появляется дополнительный смысл, а именно, «ореол запретного плода», особенно заметный на фоне описанных Е. Евтушенко явлений периода советского застоя.

\section{5. Сочетаемость}

Мы не стремились провести исчерпывающий анализ сочетаемости ключевых лексем, что, впрочем, в рамках настоящей работы и невозможно. Отметим лишь некоторые характерные детали, например, атрибутивной сочетаемости.

Так, сочетание гнилой апельсин присутствует в ряде текстов корпуса:

(5) Она могла бы ужиться во всяком положении: торговать на Сенной вареным картофелем или гнильми апельсинами, содержать дом терпимости, быть смотрительницей в тюрьме, состоять сиделкой при больном, исполнять должность палача (А. К. Шеллер-Михайлов: Лес рубят - щепки летят, 1871).

(6) В коридоре появился Самсонов, нагруженный гнилыми апельсинами в авоське (Елена и Валерий Гордеевы: Не все мы умрем, 2002).

Сочетание гнилой ананас в НКРЯ вообще не представлено (хотя вполне приемлемо), а в Рунете это, как правило, буквальное понимание, например, в советах покупателям, как правильно выбрать в гипермаркете свежий, а не гнилой ананас. Конечно, на основании этих отдельных фактов нельзя делать далеко идущих выводов, но тем не менее возникает ощущение, что обычность сочетания гнилой апельсин говорит о том, что сам апельсин является в русском сознании более «банальным» фруктом, т. к. запросто может быть как свежим, так и гнилым, без какой бы то ни было дополнительной ассоциативной связи (см. ниже и в разделе о городском фольклоре), а в случае с ананасом это не так: его «положительная эксклюзивность» как бы мешает соотносить его с чем-то неприятным, отталкивающим - гнилым (ср., например, и со следующим контекстом: «Пахло водкой, прокисшими апельсинами, скипидаром, которым дядя спасался от моли, кофейной гущей, что в общем давало пронзительную кислятину...» (А. П. Чехов: Оба лучше, 1884-1885). 
Обычные атрибуты к существительному ананас: спелье, зрелье, сладкие, душистые, сочные, крупные, консервированные, импортные ананасы.

Нетривиальные атрибуты (приятный, приторный, незрельй, убогий ананас) и необычное потребление плода сигнализируют разные степени смысловой реинтерпретации:

(7) Как в большом лесу дуб, вяз, сосна и тополь, соплетая различные свои ветви, растут в сладком согласии, без всякия помощи рук человеческих, - равно здесь, приятно между собою смешанные, рождаются померанцы златовидные, свежие оливы, желтые лимоны, мшистые персики и яблоки прозрачные; единое древо кажется вдруг носити все сии плоды, - толь тесно ветви их сплетенны; ослепляется око живостию цветов толиких, и ароматы их суть то же самое для обоняния, что для вкусу приятный ананас, соединяющий в себе всех прочих плодов приятность (Д. И. Фонвизин: Иосиф [перевод поэмы П. Ж. Битобе с французского], 1769).

(8) Я так пышно скучала, так рассеянно грустила, так неистово радовалась, что ты бы сочла меня за отаитянку на парижском бале, и поверишь ли: я уж испытала, ma cherie, что удивление - прескучная вещь и что новость приторнее ананасов (А. А. Бестужев-Марлинский: Фрегат «Надежда», 1833).

(9) Незрельй ананас, для человека справедливого, всегда хуже зрелой смородины (Козьма Прутков: Плоды раздумья. Мысли и афоризмы, 1854-1860).

(10) Бегемот отрезал кусок ананаса, посолил его, поперчил, съел и после этого так залихватски тяпнул вторую стопку спирта, что все зааплодировали. После второй стопки, выпитой Маргаритой, свечи в канделябрах разгорелись поярче, и в камине прибавилось пламени (М. А. Булгаков: Мастер и Маргарита. Ч. 2., 1929-1940).

(11) Ничего другого более соответствующего нынешнему техническому состоянию путинской армии, кроме этого убогого ананаса, насаженного на ножи, не придумать (Владислав Шурыгин: Удел нищих. // «Завтра», 20.06.2003).

В примере (7) представлено атипичное для современной нормы сочетание (приятный ананас), и можно лишь предположить, что в XVIII веке такая сочетаемость была связана с несколько иным в то время спектром семантики прилагательного приятный, а не с качествами самого ананаса. Пример (8) атипичен из-за необычности самого текста (его неестественность, «манерность»), что подчеркивает и другое неестественное сочетание в нем: пышно скучала. Примеры (9) и (10) входят в прецедентные тексты, которые своей известностью делают приемлемым любое употребление, от «банального» незрелый ананас до абсурдного посолить/поперчить ананас.

Пример (11) требует особого комментария, т. к. связан с другим окказиональным сочетанием: путинский ананас. Такое прозвище в начале 2000-х гг. в российских армейских кругах получила новая эмблема сухопутных войск, визуально представлявшая собою пехотную гранату (на штыках), напоминающую по форме... ананас. Поэтому окказиональное сочетание убогий ананас появляется в статье, в которой резко критикуется тогдашнее состояние (боеспособность, материальное обеспечение) российской армии. Так возникает 
неожиданная авторская метафора, которую можно сравнить разве что с метафорой знаменитого поэта современности Е. Евтушенко, см. пример (12): морковку хрущевской «оттепели» - кубинский ананас. Стоит обратить внимание на то, что ананас сравнивался с гранатой (бомбой) и раньше (см. пункт 4).

\section{6. География ананаса и апельсина}

Интересны примеры из «географии» анализируемых нами фруктов:

(12) В другой руке я держал за зеленый хвостик морковку хрущевской «оттепели» - кубинский ананас (Евгений Евтушенко: «Волчий паспорт», 1999).

(13) Сперва ананасы не понравились, когда матросики принялись было их есть с кожей, нечищеными, и покололи губы; однако вскоре, когда недоразумения были отстранены, то есть кожа снята, они вошли во вкус и лакомились вволю чудными сочными и крупными батавскими ананасами, которые продавались очень дешево (К. М. Станюкович: Вокруг света на Коршуне, 1895).

Встречаются также ананасы мексиканские и африканские.

Атрибутивная сочетаемость апельсина «по географии» куда разнообразнее и многоречивее. Рассмотрим примеры:

(14) Впрочем фуэские апельсинь далеко не так хороши как розетские, считаемые лучшими в Египте, и действительно превосходные (А. А. Рафалович: Путешествие по Нижнему Египту и внутренним областям Дельты, 1850).

(15) Равнодушными сперва взглядами скользили мы по скучноватым, плоским берегам Палестины и Сирии; промелькнули издали апельсинники Кайфы, неизвестные европейцам, но знаменитые здесь (яффские апельсины ничто перед кайфскими)... (Андрей Белый: Между двух революций, 1934).

(16) Реки текут под песками, но вода в них горькая, как кожа персидского апельсина (К. Г. Паустовский: Кара-Бугаз, 1932).

(17) Методами гибридизации Зорин создал так называемый «сочинский апельсин», плоды которого созревают одновременно с мандаринами, во второй половине ноября (А. И. Векслер: Мичуринское преобразование советских субтропиков. // «Наука и жизнь», 1949).

(18) В руках он держал плетенку, в которой золотились огромные мессинские апельсины, а обоими локтями прижимал бутылки вина, оплетенные соломкой (Борис Полевой: Ваня Терачини. // «Огонек», 1959/2).

(19) У пилотов с виду работа нетрудная: спросил у штурмана курс, поправил автопилот - и пей холодный нарзан, очищай австралийские апельсины (Василий Песков: Белые сны, 1964).

(20) В Талый пароход пришел с марокканскими апельсинами (Василий Аксенов: Апельсины из Марокко, 1962).

Эти контексты можно условно разделить на досоветские и советские. Первые (14-16) просто включают в себя абсолютно нетипичные (из-за внешнеполитической изолированности СССР) для последующего периода географические названия, вторые же (17-19) можно рассматривать как специфику 
советской эпохи, например - город Сочи как «советские субтропики». Отметим здесь и особую роль марокканских апельсинов (20). В отличие от всех прочих контекстов здесь речь идет уже не только о географии, и причина понятна: повесть В. Аксенова заняла особое место в литературе «шестидесятников». Прецедентность марокканских апельсинов подтверждает и фрагмент текста недавнего лауреата Нобелевской премии, советской и белорусской писательницы С. Алексиевич:

(21) Говорят, в других странах «протезники» на горных лыжах катаются, играют в теннис, танцуют. Купите их на валюту вместо французской косметики... Вместо кубинского сахара... Марокканских апельсинов... Мне двадцать два года, вся жизнь впереди. Надо жену искать. Была девушка (Светлана Алексиевич: Цинковые мальчики, 1984-1994).

От трагедий афганской войны та же «география» может вывести нас к актуальной сегодня в России теме санкций и импортозамещения. Очевидно, император Николай Второй не издавал указа об импортозамещении, но фактически появилось оно именно во время его правления:

(22) Батумские апельсины. Отсутствие привоза в Россию из Италии апельсинов и мандаринов сослужило большую службу в смысле ознакомления русской публики с нашими отечественными апельсинами (Батумские апельсины. // «Петроградский листок», 23.12.1914).

(23) Кавказские апельсины и лимоны. По Московско-Казанской жел. дороге доставлены в Москву четыре вагона кавказских апельсинов, мандаринов $и$ лимонов. Доставка эта сделана в виде опыта сухумским садовладельцем Смецким с изелью ознакомлены русского общества с кавказскими фруктами, которые в количестве 4,000 пудов собраны им с площади сада в пять десятин. Три вагона предназначены для Москвы, где фрукты поступят в продажу, а один вагон будет отправлен в Петроград. По отзывам специалистов, фрукты прибыли в самом хорошем состоянии (Московское утро, 10 декабря. // «Вечернее время», 23.12.1914).

\section{3. Апельсины и ананасы в русской литературе (Ананасы в шампанском и очищенные апельсины)}

В этом месте автор настоящей статьи, детство которого прошло в брежневскую эпоху тотального дефицита, должен признаться, почему он остановил свое внимание именно на апельсине и ананасе. Перечитывая сегодня русскую классику, лингвист поневоле сосредоточит свой взгляд на таких деталях текста, на которые ранее (в детстве - юности) просто бы не обратил внимание. Вот один из таких фрагментов:

(24) Какой-нибудь торговке, которая продает на Воскресенском мосту очищенные апельсины, можно сидеть без носа; но, имея в виду получить... притом будучи во многих домах знаком с дамами: Чехтарева, статская советница, и другие... (Н. В. Гоголь: Нос, 1836). 
Что удивительного в этом отрывке знаменитого рассказа Н. В. Гоголя? Удивителен здесь не пропавший нос, а тот банальный факт, что в 1836 году какая-то торговка могла запросто продавать очищенные апельсины на улицах Петербурга. Очевидно, это было совершенно нормально, обыденно. Не так, как в эпоху «победившего социализма»:

(25) Однажды на такую репетицию попал и я, запомнил, что очень вкусно кормили, подали даже апельсины, что было тогда большой редкостью (С. М. Голицын: Записки уцелевшего, 1980-1989).

(26) Вспоминаю, как однажды, получив из Ленинграда известие о тяжелой болезни сына одного из друзей, она бегала целый день по Москве, во всех буфетах покупая апельсинь: мальчику разрешено было питаться одним лишь апельсиновым соком, а в Ленинграде фруктов вообще в эти дни не было (Л. К. Чуковская: Памяти Фриды, 1966-1967).

Сегодня, конечно, можно много иронизировать на бесконечные темы о том, какова была жизнь в России «до исторического материализма», но все же трудно пройти мимо такого контекста, где описан режим содержания государственных преступников - народников - в царских тюрьмах:

(27) В этот день Окладскому вместо обеда, который полагался по ссыльно-каторжному режиму, дали обед как для подследственного арестанта: борщ с мясом, жаркое из дичи и на сладкое апельсин (Ю. В. Трифонов: Нетерпение, 1973).

А вот какие ассоциации вызвали у жены великого поэта «послереволюционные», «нэповские» апельсины:

(28) Катаев угощал нас новым для Москвы испанским вином и новыми апельсинами - они появились в продаже впервые после революции. Все, «как прежде», даже апельсины! (Надежда Мандельштам: Воспоминания, 1970).

Апельсин появляется во многих текстах как некий индикатор «нормальности» жизни, благосостояния. Вот и после-перестроечная «ностальгия»:

(29) Ну, знаешь, Дед Мороз, подарки и все такое. Классно так было. - А теперь? - A теперь апельсины кругльй год продают. Я уж и не помню какое они должны вызывать настроение. - Да, у тебя большие проблемы. - Нет, я серьезно (Андрей Геласимов: Год обмана, 2003).

\section{1. Яблоко раздора и апельсин примирения}

Известный древний фразеологизм (яблоко раздора) приведен нами здесь лишь в целях достижения смыслового контраста с содержанием следующего текста. П. В. Анненков так описывает один примечательный случай во время встречи с Н. В. Гоголем, который в описываемое время «был занят внутренней работой, которая началась для него со второго тома „Мертвых душ“»: 
(30) Гоголь говорил резко, деспотически, отрывисто. Ради честности, необходимой даже в застольной беседе, я принужден был невольно указать на несколько фактов, значение и важность которых для цивилизации вообще признаваемы всеми. Гоголь отвечал горячо и тем, вероятно, поднял тон моего возражения; однакож спор тотчас же упал в одно время с обеих сторон, как только сделалась ощутительна в нем некоторая степень напряжения. Молча вышли мы из австерии, но после немногих задумчивых шагов Гоголь подбежал к первой лавочке лимонадчика, раскинутой на улице, каких много бывает в Риме, выбрал два апельсина и, возвратясь к нам, подал с серьезной миной один из них мне. Апельсин этот меня тронул: он делался, так сказать, формулой, посредством которой Гоголь выразил внутреннюю потребность некоторого рода уступки и примирения (П. В. Анненков: Гоголь в Риме летом 1841 года, 1857).

О символьном значении апельсинов в культовой повести 1960-х годов «Апельсины из Марокко» В. Аксенова свидетельствуют многочисленные места в тексте этого литературного произведения. Однако в наши цели, естественно, не входит литературоведческий анализ всех контекстов с ананасом и апельсином в русской литературе, поэтому здесь мы лишь сжато укажем на некоторые избранные, впрочем, хорошо известные факты из истории отечественной литературы.

По признанию В. Маяковского, его увлечение поэзией началось со строки Андрея Белого «В небеса запустил ананасом». Это совсем не удивительно: в статье «Ананас на русской почве: О стихотворении Андрея Белого» литературоведа В. В. Абашева дан подробный и достаточно своеобразный анализ этого произведения (АБАшев 2002), ${ }^{8}$ к этой статье мы и отошлем любопытного читателя. В. В. Абашев так объясняет свой профессиональный интерес:

Выбор именно этого текста для разбора легко объясним: ни одно из отдельных стихотворений поэта не удостаивалось столь повышенного внимания, как это. После выхода книги оно превратилось в своего рода эмблему, опознавательный знак Андрея Белого. Об этом эффекте писал Ремизов: «От каждого да останется хоть какой-нибудь гульдик и что годами повторяется, пока не выпенится имя автора. „О закрой свои бледные ноги“ (Брюсов), „Люблю себя, как Бога“ (З. Гиппиус), „Запустил в небеса ананасом“ (Андрей Белый)». Строки про горбуна, запустившего в небо ананасом, как вспоминал Борис Зайцев, обошли все российские газеты, их не обделил вниманием ни один из рецензентов и пародистов (АБАШЕВ 2002: 123).

Заметим лишь то, что включенная в заглавие настоящей статьи другая культовая фраза (см. выше рекомендацию к употреблению ананаса в «Книге о вкусной и здоровой пище») ананасы в шампанском из не менее знамени-

8 «Если суммировать итоги экскурса в культурную историю ананаса, то выстраивается стабильная цепочка символических атрибуций, ананас - культурно-бытовая эмблема роскошного и чувственного дворянского века, прежде всего XVIII, ананас - эмблема эротизма, нередко выступающая как прямая фаллическая метафора» (АБАшЕв 2002: 132). 
того стихотворения И. Северянина появилась «с подачи» того же В. Маяковского: якобы именно ему во время застолья у И. Северянина пришло в голову опустить в бокал с шампанским кусочки ананаса. Естественно, и здесь мы опустим анализ уже почти хрестоматийного произведения, указав лишь на тот факт, что само сочетание ананасы в шампанском стало поистине крылатым, и встречается в самых разных аспектах в многочисленных литературных и культурных контекстах. Нельзя исключить, что своей популярностью эта фраза отчасти обязана другому «крылатому» выражению: кто не рискуem, mот не пьет шампанского (БЕРков-МокИЕНко-ШуЛЕжКоВА 1: 547; заметим, что мнения об источнике этой фразы расходятся).

\section{4. Апельсины (и ананасы) в русской фразеологии и в городском фольклоре}

Во фразеологии современного русского языка самыми известными фраземами с компонентом апельсин являются, безусловно, выражения грузите апельсины бочками (МокиЕнко-НикитинА 2007: 18) и разбираться как свинья в апельсинах (STĚPANOVA 2007). Искаженная цитата грузите апельсинь бочками имеет хорошо известный литературный источник - роман И. Ильфа и Е. Петрова «Золотой теленок» (1931 г.), в котором Великий Комбинатор ведет психологическую атаку «подпольного миллионера Корейко» с помощью абсурдных телеграмм:

Александр Иванович побледнел от злости и разорвал телеграмму в клочки. Но в эту же ночь принесли еще две телеграммы-молнии. Первая; «Грузите апельсины бочках братья Карамазовы». И вторая: «Лед тронулся тчк командовать парадом буду я». После этого с Александром Ивановичем произошел на службе обидный казус (И. Ильф, Е. Петров: Золотой теленок, 1931).

Александр Иванович, приучивший себя к экономии, потушил настольную лампу и сказал: - Так это вы посылали мне дурацкие телеграммы? - Я, - ответил Остап. - «Грузите апельсины бочках братья Карамазовы». Разве плохо? - Глуповато. - А нищий - полуидиот? (И. Ильф, Е. Петров: Золотой теленок, 1931).

О славянских и прочих параллелях фраземы разбираться как свинья в апельсинах много написано в специальной литературе (см. МоKIENKo 2013: XII). Менее известной является «переделка» у осинки не родятся апельсинки (см. АРН 2005: 29), «прототипом» для которой стала традиционная пословица груши на вербе не растут. А вот ананасов в русской фразеологии нет, если не считать особыми видами фразем приведенные выше поэтические цитаты запустил в небеса ананасом и ананасы в шампанском.

Пожалуй, более ярко представлены апельсин и ананас не во фразеологии, а в т. н. городском фольклоре. Внешняя схожесть ананаса с гранатой (бомбой) послужила (ср. выше о выражении путинский ананас) основой и для следующего стишка: 
Вовка в сарае нашел ананас

И не подумал, что это фугас

Стал его резать, стал его есть

Ножик нашли километров за шесть.

Популярен ананас и как основа для языковой игры, например, в следующих субстандартных анекдотах:

- Почему слово квас пишется вместе, а к вам - отдельно?

- Потому что ананас пишется вместе, а мы ее - отдельно.

Учительница: - Дети, придумайте предложение со словом ананас.

Вовочка: - Папа пошел к б...м. - А где же слово ананас? - A на нас с мамой х... положил!

А вот так представлен, к примеру, уже упоминавшийся нами выше гнилой апельсин в современном песенном «творчестве»:

Что будет, если съесть гнилой апельсин, или «клип» на песню Маленький гнилой апельсинчик мой!

Есть у меня один

Маленький апельсин,

Маленький гнилой

Апельсинчик мой.

Сейчас его я съем, Станет моим совсем.

Маленький гнилой

Апельсинчик мой.
Вот его я съел,

Стал он моим совсем.

Маленький гнилой

Апельсинчик мой.

Я на горшке сижу, аaаaа!

И в потолок гляжу, аaаaа!

А во всем виноват

Круглый оранжевый гад.

\section{5. Заключение}

В статье Б. Л. Иомдина и А. Ч. Пиперски о прагматике еды высказывается мысль о том, что словарные толкования таких лексем, как, например, хлеб ('пищевой продукт, выпекаемый из муки') и соль не являются не только исчерпывающими, но даже и дифференциальными, т. к. под них (для хлеб) подходят все мучные изделия и т. д.:

Тот факт, что хлеб и соль имеют в русском языке прочные ассоциации 'основного, необходимого' (хлеб - основная пища, соль - необходимая составляющая любой трапезы), подтверждается богатейшим материалом, многократно отмечался и не требует дополнительных комментариев. По всем критериям эти ассоциации безусловно являются коннотациями лексем хлеб и соль. Однако такое решение явным образом противоречит основному свойству коннотаций, поскольку те по определению воплощают несущественные признаки понятия, выражаемого лексемой [...]. Кажется более разумным включение этих важнейших для представления о хлебе и соли в русской языковой картине мира признаков в толкование лексем (Иомдин-ПипЕРски 2010: 156). 
Апельсин и ананас, безусловно, не являются основной пищей и необходимой составляющей трапезы в русской культурной среде. Однако и за ними закреплены - как мы видели - прочные ассоциации в АВС носителей языка, хотя об их лингвоспецифичности говорить не приходится. Разница скорее состоит в том, что в многочисленной «семье» цитрусовых за такими фруктами, как лаймы, померанцыь, бергамоты, клементины, кумкваты, лайкваты, помело, циитроны и т. д. в русском языке не закреплены никакие коннотации, их самих попросту нет в русском культурном контексте - в отличие от ключевых слов нашего исследования. Такая включенность в культурный контекст делает эти названия еды знаками культурного кода. Вопрос же о лексикографической фиксации таких специфических лексем со сложной семантикой и прагматическими свойствами остается, однако, открытым.

\section{Литература}

АБАшев 2002 = АБАшев В. В. Ананас на русской почве. О стихотворении Андрея Белого «На горах». Russian Literature 51 (2002): 121-143.

АРН 2005 = ВАЛЬТЕР Х., МокИЕнкО В. М. Антипословицы русского народа. СанктПетербург: «Нева», 2005.

БАРАНОВ 2015 = БАРАНОВ А. Н. Справедливость versus несправедливость: метафорические осмысления в современном российском дискурсе (по материалам центральных печатных изданий). В кн.: Компьютерная лингвистика и интеллектуальные технологии. Вып. 14. Т. 1. Москва: Издательство РГГУ, 2015. 19-29.

БЕРКОВ-МОКИЕНКО-ШУЛЕЖКОВА = БЕРКОВ В. П., МОКИЕНКО В. М., ШУЛЕЖКОВА С. Г. Большой словарь крылатых слов и выражений русского языка. Т. 1-2. Магнитогорск-Greifswald, 2008.

Иомдин 2015 = Иомдин Б. Л. Что такое орехи? В кн.: Компьютерная лингвистика $и$ интеллектуальные технологии. Вып. 14. Т. 1. Москва: РГГУ, 2015. 214-230.

Иомдин-ПиПЕРски 2010 = Иомдин Б. Л., ПиПЕРски А. Ч. Прагматика еды: коннотации в русской и немецкой пищевой лексике. В кн.: Компьютерная лингвистика и интеллектуальныле технологии. Вып. 9. Москва: РГГУ, 2010. 151-156.

МОКИЕНКО-НИКИТИНА 2007 = МокиЕНКо В. М., НикитинА Т. Г. Большой словарь русских поговорок. Москва: «ОЛМА Медиа Групп», 2007.

ПокРОвский 1988 = ПокРОвСКИй А. А. и др. (ред.) Книга о вкусной и здоровой пище. Изд. 8-е, испр. и доп. Москва: «Агропромиздат», 1988.

РАС = КАРАУЛОВ Ю. Н. (ред.) Русский ассоциативный словарь. Т. 1-2. Москва: ИРЯ PAH, 1994.

BÁRdOSI 2003 = BÁRdosi Vilmos: Magyar szólástár. Budapest: Tinta, 2003.

BÁRDOSI 2015 = BÁRDOSI Vilmos: Szólások, közmondások eredete. Budapest: Tinta, 2015.

ÉKSz. = JuHÁsz József et al. (szerk.): Magyar értelmezö kéziszótár I-II. Budapest: Akadémiai Kiadó, 1985.

MoKIENKo 2013 = MoKIENKo V. Václav Flajšhans jako předvoj Evropské unie paremiologické. In: FlajšHans V. Česká př́sloví. D. 2. Olomouc: UP, 2013. III-XIII.

O. NAGY $1994=$ O. NAGY Gábor: Magyar szólások és közmondások. Budapest: GondolatTalentum, 1994.

STĚPANOVA 2007 = STĚPANOVA L. Rusko-českýfrazeologickýslovník. Olomouc: UP, 2007. 